\title{
GROWTH AND PHYSIOLOGY OF YOUNG GRAPEVINES (CV. BRS CARMEM) UNDER ORGANIC AND BIODYNAMIC PRODUCTION SYSTEMS
}

\author{
Rafael Piva ${ }^{1}$, Renato Vasconcelos Botelho ${ }^{1}$, Patrícia Carla Giloni de Lima ${ }^{2}$, Adamo Domenico Rombolà ${ }^{3}$
}

\begin{abstract}
The biodynamic cultivation method consists of seeing the farm as an agricultural organism; its main goal is soil fertility, along with a rich diversity and biological activity. The objective of this work was to evaluate the growth, the physiology and the yield of grapevines cv. BRS Carmem, comparing organic and biodynamic production systems. The experiment was conducted under field conditions in Guarapuava, Paraná State, Southern Brazil, and the grapevines were planted in September 2013 and evaluated until June 2017. The experimental design was a randomized block with two treatments and six replications. In the plots of biodynamic treatment the following biodynamic preparations were applied: silica horn (501), manure horn (500), 508 (Equisetum hyemale L.) and Fladen. All plants were fertilized with the same organic compost, however, those from the biodynamic treatment received the preparations 502 (Achillea millefolium), 503 (Chamomilla officinalis), 504 (Urtica dioica), 505 (Quercus robus), 506 (Taraxacum officinale) and 507 (Valeriana officinalis). During three consecutive growing seasons the following variables were evaluated: enzyme activity (EC 3.2.1.39) $\beta$ 1,3 glucanase and (EC 3.2.1.14) chitinase, mildew severity Plasmopara viticola, leaf water potential, gas exchange, chlorophyll fluorescence, SPAD index, measurements of length and diameter of the canes, trunk diameter, weight of the pruning material, number of clusters, cluster length, berry diameter and soluble solids concentration. Biodynamic treatment promoted at least one year greater growth of plants (length and diameter of canes, trunk diameter and SPAD index), better physiological response (leaf photosynthetic activity, Rubisco enzyme efficiency and maximum quantum yield of PSII), biochemistry ( $\beta$ 1,3 glucanases and chitinase enzymes) and consequently greater resistance to disease and productivity.
\end{abstract}

Keywords: agroecology, enzymes, photosynthesis, vegetative growth, Vitis spp.

\section{CRESCIMENTO E FISIOLOGIA DE VIDEIRAS (CV. BRS CARMEM) EM SISTEMA ORGÂAICO E BIODINÂMICO DE PRODUÇÃO}

\begin{abstract}
RESUMO - O método biodinâmico de produção consiste em analisar a propriedade rural como um organismo; com foco na fertilidade do solo juntamente com uma rica diversidade e atividade biológica. $O$ objetivo deste trabalho foi avaliar o crescimento, a fisiologia e a produção de videiras cv. BRS Carmem, comparando o sistema orgânico e biodinâmico de produção. O experimento foi conduzido em condições de campo em Guarapuava, Paraná, sul do Brasil, e as videiras foram plantadas em setembro de 2013 e avaliado até junho de 2017. O delineamento experimental foi em blocos casualizados com dois tratamentos e seis repetições. Nas parcelas de tratamento biodinâmico, foram aplicados os seguintes preparados biodinâmicos: chifre de sílica (501), chifre de esterco (500), 508 (Equisetum hyemale L.) e Fladen. Todas as plantas foram fertilizadas com o mesmo composto orgânico; no entanto, as do tratamento biodinâmico receberam os preparados 502 (Achillea millefolium), 503 (Chamomilla officinalis), 504 (Urtica dioica), 505 (Quercus robus), 506 (Taraxacum officinale) e 507 (Valeriana officinalis). Durante três épocas de cultivo consecutivas, foram avaliadas as seguintes variáveis: atividade enzimática (EC 3.2.1.39) $\beta$ 1,3 glucanase e (EC 3.2.1.14) quitinase, severidade de oídio Plasmopara viticola, potencial de água nas folhas, trocas

\footnotetext{
${ }^{1}$ Department of Agronomy, State University of Middle Western-Unicentro, R. Simeão Camargo Varella de Sá 03,CEP 85040-080 Guarapuava, Paraná, Brazil. E-mail: raffaelepiva@gmail.com; rbotelho@unicentro.br

${ }^{2}$ Department of Biology, State University of Middle Western-Unicentro, R. Simeão Camargo Varella de Sá 03,CEP 85040-080 Guarapuava, Paraná, Brazil. E-mail: pgiloni2012@gmail.com

${ }^{3}$ Department of Agricultural and Food Sciences, Alma Mater Studiorum University of Bologna, Viale G. Fanin, 44, 40127 Bologna, Italy. E-mail: adamo.rombola@unibo.it
} 
gasosas, fluorescência de clorofila, indice SPAD, medidas do comprimento e diâmetro dos ramos, diâmetro do tronco, peso do material de poda, número de cachos, comprimento dos cachos, diâmetro das bagas e concentração de sólidos solúveis. O tratamento biodinâmico promoveu em ao menos um ano maior crescimento das plantas (comprimento e diametro dos ramos, diâmetro do tronco e índice SPAD), melhor resposta fisiológica (atividade fotossintética das folhas, eficiência da enzima Rubisco e rendimento quântico máximo de PSII), bioquímica (enzimas $\beta$ 1,3 glucanase e quitinase) e consequentemente maior resistência a doenças e produtividade.

Palavras chave: agroecologia, crescimento vegetativo, enzimas, fotossintese, Vitis spp.

\section{INTRODUCTION}

With increased consumer demand for uncontaminated or not genetically modified products, the number of producers working in organic agriculture has increased every year. There are more than 170 countries with organic agriculture in the world, in more than 43 million hectares, especially Australia (17.2 million ha), Argentina (3.1 million ha) and USA (2.2 million ha), which represents $1 \%$ of the world's arable land (Willer and Lernoud, 2016).

About 164,000 hectares worldwide are certified by Demeter as biodynamic in 4,956 properties (Demeter, 2016). Germany has the largest certified area of 67,000 hectares, followed by France, Italy, the Netherlands, Spain, Hungary and India. According to Demeter International (2016), Brazil has an area currently certified of 3,765 hectares in more than 30 farms. The main biodynamic products are coffee, cocoa, soy, brown sugar, mate, orange juice, dried fruits, cashew nuts, palm oil, palm hearts, guaraná, rice, citrus fruits and animals (Ibd, 2016).

Biodynamic viticulture is spreading faster in Argentina, Chile and France, and today there are more than 708 farms certified by Demeter in more than 9,533 hectares of area for the production of wine grapes. In the juice production, the highlight is for Italy and Spain. Table grapes occupy an area of 624.5 hectares and 140 producers (Demeter, 2016).

There are few data on biodynamic viticulture in Brazil. There are some farms producing grapes for wine (Vitis vinifera L.) following the biodynamic system, but they are not certified (Medeiros, et al. 2014). The first biodynamic wine produced was Imortali 2012, being elaborated by the Santa Augusta winery in Água Doce, Santa Catarina, in an area of 5.5 hectares with Cabernet Sauvignon and Cabernet Franc (Rauta et al., 2014). The same winery has another area in Videira SC, and adds 14 hectares of vineyards in a biodynamic system. There are other areas in the process of conversion or implantation in the states of Rio Grande do Sul, Santa Catarina and Minas Gerais, and together they totalize approximately 27 hectares.

According to (Steiner, 1924), the method of biodynamic cultivation consists of seeing the property as an agricultural organism and understanding the different components (soil, water, plants, animals and man), their potentials and their limitations. Many studies show the influence of the biodynamic preparations in organic composts, soil microbiology, crops and in the lower environmental impact or small influence (Reganold and Palmer, 1995; Carpenter-Boggs et al., 2000; Zaller and Köpke, 2004; Fließbach et al. 2007; Botelho et al., 2016; Piva et al., 2019).

Results regarding the effects on plants and fruits were observed by Reeve et al. (2005) that conducted a long-term study with cv. Merlot, and investigated the effects of biodynamic preparations on soil in plants and grape quality. Vines treated with biodynamic preparations had significantly higher soluble solids content, higher polyphenols and total anthocyanins content. Botelho et al. (2016) worked with cv. Sangiovese in Italy, and compared organic and biodynamic management for three cycles. In their study, several soil parameters, gaseous exchanges, water potential, leaf enzymatic activity ( $\beta 1,3$ glucanese and chitinase) and yield were analyzed. As results, it was verified that plants of the biodynamic treatment presented lower stomatal conductance and leaf water potential and increased foliar enzymatic activity.

The objectives of the present study were to determine if the application / use of biodynamic preparations 500 (Horn-manure), 501 (Horn-silica), Fladen, 502 (Achillea millefolium L.), 503 (Chamomilla officinalis L.), 504 (Urtica dioica L.), 505 (Quercus robus L.), 506 (Taraxacum officinale Web), 507 (Valeriana officinalis L.) and 508 (Equisetum hyemale L.) influence the development, physiology and production of grapevines cv. BRS Carmem. 


\section{MATERIALS AND METHODS}

\section{Experimental design and vineyard management}

The experiment was carried out in Guarapuava, Paraná State, Brazil, with geographic coordinates of $25^{\circ}$ $41^{\prime} \mathrm{S}$ and $51^{\circ} 38^{\prime} \mathrm{O}$ and altitude of 1100 meters. The climate according to the classification of Köppen is of the type $\mathrm{Cfb}$ (subtropical mesothermic moist), temperate, without dry season defined, with hot summer and moderate winter (Wrege et al., 2011).

The plantlets of cv. Carmem grafted on the rootstock 'Paulsen 1103' were planted on September 21, 2013, spaced 3 meters between rows and 1.5 meters between plants, corresponding to a density of 2,222 plants $\mathrm{ha}^{-1}$. The experimental design was a randomized block, with two treatments and six replicates and experimental plot consisting of six plants. The treatments were as follows:

T1) Organic: based on organic production standards (IN 46/2011, Mapa, 2011); including maintenance fertilizer with the same manure used in the composting of the biodynamic model, but without the prepared biodynamic.

T2) Biodynamic: based on the precepts of biodynamic agriculture including the use of preparations according of Demeter standards (Jovchelevich \& Vidal 2016).

\section{Pest and disease management and biodynamic preparation}

The commercial products used regularly for preventive spraying during the sprouting and fruiting period (September-March) alternate every 15 days throughout the experimental area: Fish Fértil ${ }^{\circ} 20 \mathrm{~g} \mathrm{~L}^{-1}$ (chitosan, Fish Industry and Trade of Fertilizers Ltda, Mogi Mirim, SP, Brazil), Natualho® $700 \mathrm{~mL} \mathrm{~L}^{-1}$ a.i (garlic extract, Natural Rural, Araraquara, SP, Brazil), Bordatec $\AA 20{\mathrm{~g} 20 \mathrm{~L}^{-1}}^{-1}$ (lime and copper sulfate, Tecnofol Fertilizers Ltda, Itajaí, SC, Brazil), and Nim I Go® 2000 ppm neem (neem oil Agrobiotica, Leme, SP, Brazil).

The biodynamic preparations (Table 1) were divided into three groups: a) applied by spraying on the soil: 500 (Horn-manure); 508 (Equisetum hyemale L.) and Fladen; b) spraying on plants canopy: 501 (Horn-silica), and c) applied to the organic compost: 502 (Achillea millefolium L.), 503 (Chamomilla officinalis L.), 504 (Urtica dioica L.), 505 (Quercus robus L.), 506 (Taraxacum officinale

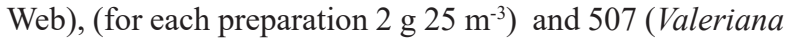
officinalis L.) (2 mL $\left.25 \mathrm{~m}^{-3}\right)$.
Table 1 - Number of applications of biodynamic preparations in each year in cv. BRS Carmem (Guarapuava-PR)

\begin{tabular}{lccccc}
\hline $\begin{array}{l}\text { Biodynamic } \\
\text { preparations }\end{array}$ & Dose & 2013 & 2014 & 2015 & 2016 \\
\hline $\begin{array}{l}\text { Fladen } \\
\text { 100 g } 30 \mathrm{~L}^{-1} \\
\text { ha }^{-1}\end{array}$ & 1 & 2 & 3 & 1 \\
$\begin{array}{l}\text { Silica horn } \\
(501)\end{array}$ & $\begin{array}{l}4 \mathrm{~g} 70 \\
\mathrm{~L}^{-1} \mathrm{ha}^{-1}\end{array}$ & 1 & 5 & 3 & 2 \\
$\begin{array}{l}\text { Manure horn } \\
(500)\end{array}$ & $\begin{array}{c}100 \mathrm{~g} 70^{-1} \mathrm{ha}^{-1} \\
\begin{array}{l}\text { Equisetum } \\
(508)\end{array}\end{array}$ & 2 & 4 & 3 & 1 \\
\hline
\end{tabular}

The organic compost was prepared with cattle manure, bean and maize straw 3:1 (straw/manure, v/v). The corn husk made the base of the pile and the compost cover, and the beans were separated by two layers of manure. For the composting, two piles of approximately $5 \mathrm{~m}^{3}$ were made with the same materials, one of which received the biodynamic preparations. The compounds were assembled in May 2014 and 2015. In the second and third cycles, four months after preparation, in September 2014 and 2015, maintenance fertilizers were carried out in all plants with their respective treatments $\left(5 \mathrm{~L}^{-1}\right.$ per plant) (Jovchelevich \& Vidal 2016).

All the plants were conducted in a similar way, and all the field interventions were done in the same day, leaving in the first year all shoots from $80 \mathrm{~cm}$. In the second year on, after the formation of the plants, the number of shoots in the evaluation plants was fixed between 10 and 12 per plant.

\section{Climatic conditions}

During the vegetative period of the plants (September/February - Spring/Summer), in the first year $(2013 / 14)$, the average maximum temperature was $25.4^{\circ} \mathrm{C}$, average temperature $20.1^{\circ} \mathrm{C}$ and minimum temperature 14.8 ${ }^{\circ} \mathrm{C}$. The mean relative humidity and the total precipitation were $69.9 \%$ and $934.8 \mathrm{~mm}$, respectively. In the second year (2014/15), the average maximum temperature was $25.9^{\circ} \mathrm{C}$, average temperature $20.8{ }^{\circ} \mathrm{C}$ and minimum temperature $15.8{ }^{\circ} \mathrm{C}$. The mean relative humidity was $72.7 \%$ and the total precipitation was $1391.9 \mathrm{~mm}$. In the third year $(2015 / 16)$, the average maximum temperature was $25.5^{\circ} \mathrm{C}$, average temperature $21.0{ }^{\circ} \mathrm{C}$ and minimum temperature 
$16.4{ }^{\circ} \mathrm{C}$. The mean relative humidity was $76.8 \%$ and the total precipitation was $1227.7 \mathrm{~mm}$.

Activity of (EC 3.2.1.39) $\beta$ 1,3 glucanases and (EC 3.2.1.14)chitinase enzymes

The samples were collected in December $2013 / 14 / 15$. The enzymatic extract was obtained by maceration of 3 leaf discs with approximately $0.4 \mathrm{~g}$ of vine leaves with liquid $\mathrm{N}_{2}$ and mechanically homogenized in 2 $\mathrm{mL}$ of $0.1 \mathrm{M}$ potassium phosphate buffer ( $\mathrm{pH} 7.0$ ) containing $0,1 \mathrm{mM}$ EDTA and $1 \%$ (w/w) PVP (poly vinylpyrrolidone) in mortar. The homogenate was centrifuged at 13,000 $\mathrm{g}$ for $30 \mathrm{~min}$ at $4{ }^{\circ} \mathrm{C}$, and the supernatant obtained was considered as an enzyme extract, which was stored at $-20{ }^{\circ} \mathrm{C}$ until analysis (Lusso \& Pascholati, 1999). The determination of the protein concentration was performed according to Bradford (1976). In $1.5 \mathrm{ml}$ of the Bradford reagent was added to each $100 \mu \mathrm{l}$ of the supernatant. After $5 \mathrm{~min}$, the absorbance at $595 \mathrm{~nm}$ was measured in a Shimadzu spectrophotometer, model UV1800, Japan. The protein concentration, expressed in $\mathrm{mg}$ per $\mathrm{mL}$ of sample (mg protein $\mathrm{mL}^{-1}$ ), was determined using a standard curve of concentrations of bovine serum albumin (BSA) from 0 to $1 \mathrm{mg} \mathrm{mL}^{-1}$. The standard curve of bovine serum albumin obtained by the Bradford method was $\mathrm{y}=1.561 \mathrm{x}+0.033$ and $\mathrm{R}^{2}: 0.982$.

The enzyme $\beta$ 1,3 glucanase was determined by the colorimetric quantification of reducing sugars released from laminarin (Vogelsang \& Barz, 1993). For the reaction, $150 \mu \mathrm{L}$ of the enzyme preparation and 150 $\mu \mathrm{L}$ laminarin $\left(2 \mathrm{mg} \mathrm{ml}^{-1}\right)$ were used and incubated for 1 hour at $40{ }^{\circ} \mathrm{C}$. In control the laminarin was added after incubation. The sugars formed were quantified by the Lever method (1972), which consists of extracting a $30 \mu \mathrm{L}$ aliquot of the previous solution and adding $1.5 \mathrm{ml}$ of the $0.5 \%$ p-hydroxybenzoic acid solution (PAHBAH) to this solution. After incubating for 10 minutes at $100{ }^{\circ} \mathrm{C}$, it was cooled on ice for 10 minutes, and the absorbance at 410 $\mathrm{nm}$ was determined. The $\beta 1,3$ glucanase activity consists of the difference between the absorbance of the sample and the control, where the standard curve for glucose was $(\mathrm{y}=0,963 \mathrm{x}), \mathrm{R}^{2}: 0,997$ where $\mathrm{y}$ is the absorbance of the concentration of reducing sugars is expressed in equivalent glucose $\mathrm{mg}^{-1} \mathrm{~h}^{-1} \mathrm{mg}^{-1}$ protein.

The enzyme (EC 3.2.1.14) chitinase was quantified by the release of soluble CM-chitin-RBV fragments from carboxymethylated chitin labeled with bright violet remazol ("Carboxy Methyl-Chitin-Remazol
Brilliant Violet", Loewe Biochemica GmbH) (Wirth \& Wolf, 1990). It was used $300 \mu \mathrm{L}$ of the extraction buffer (100 mM sodium acetate $\mathrm{pH} 5.0$ ) mixed with $100 \mu \mathrm{L}$ of enzyme extract and $200 \mu \mathrm{L}$ of "CM-chitin-RBV" $\left(2 \mathrm{mg} \mathrm{L}^{-1}\right)$. After incubation for 60 minutes at $40{ }^{\circ} \mathrm{C}$, the reaction was quenched with $200 \mu \mathrm{L}$ of $1 \mathrm{M} \mathrm{HCl}$, followed by cooling on ice and centrifuging at $10,000 \mathrm{~g}$ for $5 \mathrm{~min}$. The absorbance of the supernatant was determined at $550 \mathrm{~nm}$. The results were expressed as $\mathrm{min}^{-1} \mathrm{mg}^{-1}$ protein absorbance units (Wirth \& Wolf, 1990).

\section{Severity of mildew Plasmopara viticola}

In all the evaluation plants, 10 leaves per plant were marked and analyzed weekly with the aid of a diagrammatic scale by Buffara et al. (2014), from the appearance of the first pustules $(21 / 01 / 2014,01 / 28 / 2015$ and $11 / 23 / 2015$ ) until the defoliation or paralysis of the symptoms. The calculation of the area below the disease progress curve was based on the formula: AUCPD $=\Sigma$ (yi $+\mathrm{yi}+1) / 2 *(\mathrm{ti}+1-\mathrm{ti})$, where: $\mathrm{i}=$ number of evaluations; $\mathrm{Y}=$ mycelial growth of the pathogen (\%); $\mathrm{T}=$ time (days) (AUCPD) (Shaner \& Finney, 1977).

\section{Leaf water potential}

The leaf water potential was analyzed with the Scholander chamber (Soilmoisture, SEC-3005F01, Soilmoisture Equipment Corp.). For this evaluation annually in January 2014, 2015 and 2016, two random leaves were collected per treatment between $8^{\circ}$ and $10^{\circ}$ the annual branches, throughout the day at three different times (7:00, 11:30 p.m. and 5 p.m.). The leaves were placed one by one inside the chamber, and a small part of the leaf petiole remains out. Pressurization occured with the introduction of $\mathrm{CO}_{2}$ into the chamber, and the reading was performed when a small droplet of water formed on the petiole and the valve is locked. By observing a manometer coupled to the equipment, was is possible to see the amount of pressure $(\mathrm{MPa})$ required to form this drop of water (Scholander et al., 1965).

\section{Gas exchange and fluorescence of chlorophyll}

The gas exchanges were analyzed with the infrared gas analyzer (IRGA), Li-color LI6400XT, (Biosciences Inc., Lincoln, NE, USA). The photon flux was set at $500 \mu \mathrm{mol} / \mathrm{s}$. The evaluations were performed on fully expanded leaves, located in the middle third of the branch, obtaining the measurements in the morning 
between 9 and 10 a.m., in December 2013, 2014 and 2015. The following indices were determined: net assimilation $\left(\mathrm{CO}_{2} \mu \mathrm{mol} \mathrm{m} \mathrm{m}^{-2} \mathrm{~s}^{-1}\right)$, intercellular $\mathrm{CO}_{2}$ concentration $(\mathrm{Ci}$, $\mu \mathrm{mol} \mathrm{CO}_{2} \mathrm{~mol}^{-1}$ ), stomatal conductance (Cond, mol $\mathrm{H}_{2} \mathrm{O}$ $\left.\mathrm{m}^{-2} \mathrm{~s}^{-1}\right)$ and transpiration rate (Trmmol mmol $\mathrm{H}_{2} \mathrm{O} \mathrm{m}^{-2} \mathrm{~s}^{-1}$ ). The water use efficiency (WUE, $\times 10^{-3} \mathrm{CO}_{2} / \mathrm{H}_{2} \mathrm{O}$ ) was estimated by the relationship between $\mathrm{CO}_{2}$ assimilation and transpiration rate $(A / E)$. The efficiency of Rubisco (EF Rubisco) was estimated by the relation between $\mathrm{CO}_{2}$ assimilation and intercellular $\mathrm{CO}_{2}$ concentration $(\mathrm{A} / \mathrm{Ci})^{2}$ (Hall et al., 1993).

Fluorescence of chlorophyll was obtained by using the portable fluorometer model PAM 2500 (Heinz Walz $\mathrm{GmbH})$. The evaluations were performed in two leaves per experimental plot, in completely expanded leaves, located in the middle third of the branch, obtaining the measurements between 9:00 and 10:00 a.m., in December 2014 and 2015. In the evaluation sheets, staples were fixed for a period of 30 minutes to adapt to the dark. After adaptation, the following parameters were determined: minimum fluorescence of the leaf adapted to the dark $\left(\mathrm{F}_{\mathrm{o}}\right)$, maximum fluorescence of the leaf adapted to the dark $\left(\mathrm{F}_{\mathrm{m}}\right)$, variable fluorescence of the dark-adapted sheet $\left(\mathrm{F}_{\mathrm{v}}\right)$ estimated by the difference between $\mathrm{F}_{\mathrm{m}}-\mathrm{F}_{\mathrm{o}}$, and maximum quantum yield of PSII $\left(\mathrm{F}_{\mathrm{v}} / \mathrm{F}_{\mathrm{m}}\right)$ (Baker \& Rosenqvist, 2004).

\section{SPAD Index, length, diameter of canes and trunk}

The SPAD index was determined using a portable chlorophyll meter CFL1030 chloroflOG, (Falker Automação Agrícola, Porto Alegre, Brazil), evaluated in December $2013 / 14 / 15$ in the first leaves completely expanded from the apex, in two leaves per experimental plot (Porro et al., 2001).

Length was analyzed using a tape measure and canes and trunk diameter with a $150 \mathrm{~mm}$ Pd $150 \mathrm{~mm}$ digital caliper Vonder. The diameter of the canes was made in the second inter node and that of the trunk at $12 \mathrm{~cm}$ from the soil at the Paulsen / 1103 rootstock. All the evaluations were made in two plants per experimental plot in December 2013/14/15 (Lorenz et al., 1995).

\section{Production and statistical analysis}

On 01/02/2016 the fruits were harvested from two plants per experimental plot, were taken to the laboratory and weighed in a precision scale (Bel, Bel Equipamentos Analyticos Ltda, Piracicaba, SP), followed by measurements length of bunches $(\mathrm{cm})$, number of bunches, diameter of berries $(\mathrm{mm})$, degree brix and estimated yield per hectare.

The results were submitted to analysis of variance and the averages were compared by the T test LSD at 5\% probability, using the SISVAR program 5.3 (Ferreira, 2014).

\section{RESULTS AND DISCUSSION}

\section{Plant parameters}

The biodynamic treatment had a positive effect on the vegetative growth of BRS Carmem grapevines when compared to the standard of the organic production system under field conditions. For measurements of canes and trunk diameter (Fig. 1A and 1B), there was difference in the second and third crop cycle. The biodynamic treatment had an increase in canes diameter of $5 \%$ and $12 \%$ in relation to organic treatment, for the second and third cycles, respectively. Parameter of the trunk increases of $6 \%$ and $8 \%$, for the second and third cycles, respectively.

For the length of the canes (Fig. 1C) there was difference in the second cycle of the crop, and the biodynamic treatment was 19\% higher than the organic. For the SPAD index (Figure 1D) the biodynamic treatment was significantly higher in the third cycle, presenting a value $10 \%$ higher than the organic treatment. For the evaluation of the water potential in the leaves, there was no statistical difference in any of the evaluated cycles (Data not shown).

In a long-term work with cv. Merlot, Reeve et al. (2005) have been able to conclude that biodynamic preparations can affect the canopy and the chemical characteristics of the grapes. The prepared manure horn (500) is applied to the soil, promoting root growth, providing greater biological activity and vitality, favoring the vegetative development of the plant and the symbiotic relationships of the rhizosphere (Steiner, 1924; Klett, 2012). Chemical and molecular analyzes of the prepared manure horn (500) show a complex composition of substances, including lignin derivatives and lipids of plant and microbiological origin, this particular molecular composition makes the preparation more biologically active, promoting the growth of plants (Spaccini et al., 2012). Deffune \& Scofield (1995) studied purchased humic acids, humic acid extracted from preparation horn manure (500), oak (505) and valerian (507), fresh prepared (500) (505) (507) and indole acetic acid growth regulator (IAA) in nutrient solution at three dilutions. All caused a positive growth response in wheat seedlings in relation to control with humic acids. 
A
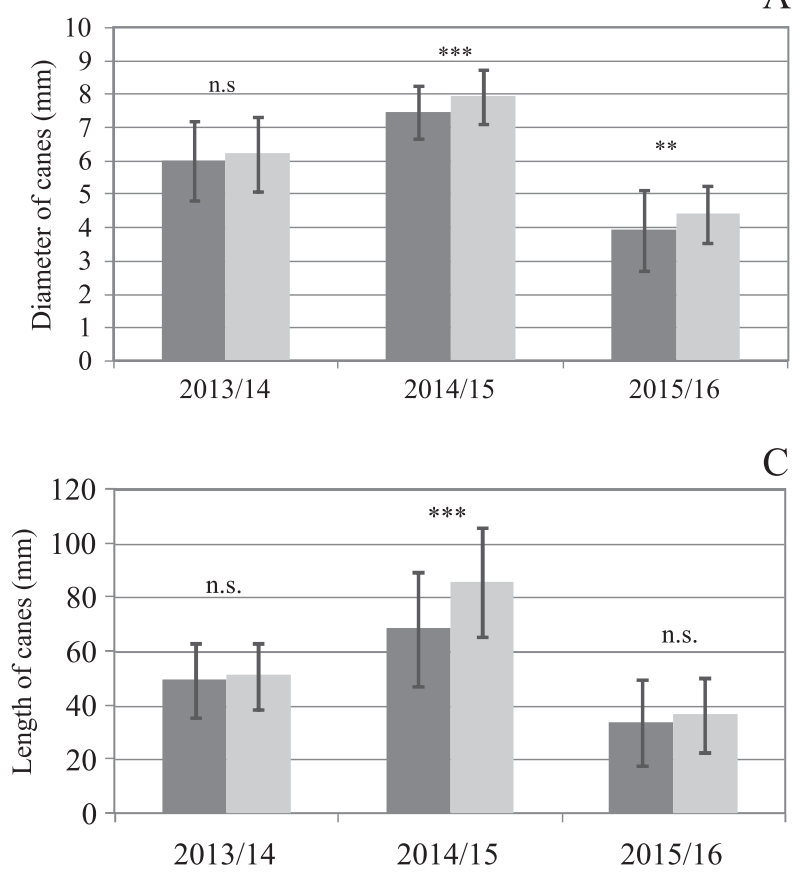

B

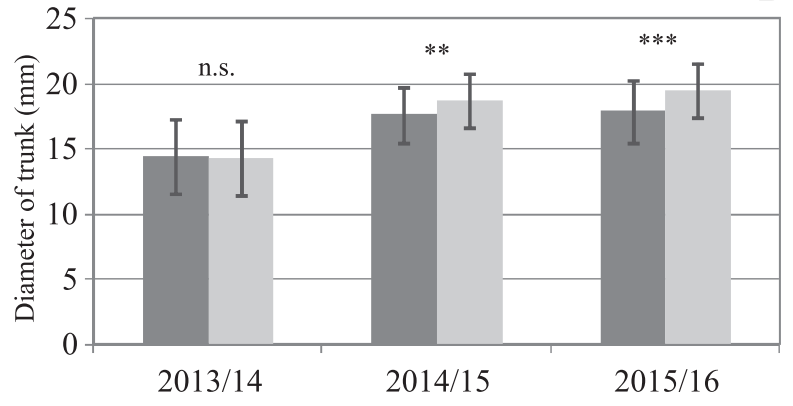

$\mathrm{D}$

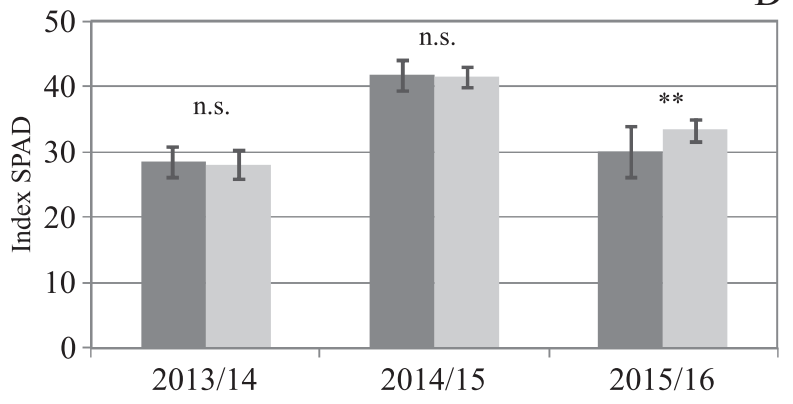

Organic Biodynamic

Figure 1 - Diameter of canes (A), trunk diameter (B) length of canes (C), and SPAD index (D) in cycles 2013/14, 2014/15 and 2015/16 of grape cv. BRS Carmem under field conditions, Guarapuava-PR, 2016, for the treatments organic and biodynamic. Differ by the T test - $\operatorname{LSD} *(\mathrm{p} \leq 0.10),{ }^{* *}(\mathrm{p} \leq 0.05), * * *(\mathrm{p} \leq 0.01)$, n.s. no significance.

\section{Gas exchange and fluorescence of chlorophyll}

The photosynthetic parameters were evaluated by three cycles. In the first and second cycles, no statistical difference was observed between the treatments (Fig. 2A, $\mathrm{B}, \mathrm{C}, \mathrm{D})$. In the third cycle, there was difference for $\mathrm{CO}_{2}$ assimilation and rubisco efficiency (Fig. 2E). Biodynamic treatment was superior in both parameters. The assimilation of $\mathrm{CO}_{2}$ was $11 \%$ higher than organic treatment, and for rubisco $16 \%$ higher efficiency. In the third cycle, water use efficiency, transpiration and stomatal conductance were not significantly different between treatments (Fig. 2F). For intracellular concentration of $\mathrm{CO}_{2}$ it was not observed statistical difference in the three cycles evaluated (Data not shown). Botelho et al. (2016) worked with the cv. Sangiovese and had reduction in the stomata conductance in the three cycles evaluated in plants with application of the biodynamic preparations, but was not observed in this study.

Chlorophyll fluorescence was evaluated for two cycles, 2014/15 and 2015/16. There was statistical difference in the 2014/15 cycle for maximum fluorescence
$(\mathrm{Fm})$, variable fluorescence $(\mathrm{Fv})$ and maximum quantum yield of PSII (Fv/Fm) (Fig. 3A). Biodynamic treatment was $18 \%$ higher for $\mathrm{Fm}, 35 \%$ for $\mathrm{Fv}$ and $13 \%$ for $\mathrm{Fv} / \mathrm{Fm}$. In the second cycle, there was statistical difference for maximum fluorescence (Fm) and variable fluorescence (Fv) (Fig. 3B). The biodynamic treatment was $11 \%$ higher for $(\mathrm{Fm})$ and $13 \%$ for $(\mathrm{Fv})$.

The biodynamic preparation Horn-silica (501) is essential for the resistance of plants and their development (Miklós, 2001; Steiner, 1924). According to Ma and Yamaji (2008), silicon exerts a beneficial effect on growth and production, as it has action on diseases, insects, drought and nutritional imbalance. According to Takahashi (1995) and Al-Aghabary et al. (2004), the use of silicon interferes in the architecture of the plants leaving the more erect leaves, allowing with this, greater penetration of sunlight, greater absorption of $\mathrm{CO}_{2}$ and less transpiration, thus generating greater efficiency and increase in photosynthesis, resulting in greater productivity. The photosynthetic parameters changed in the third cycle, where $\mathrm{CO}_{2}$ assimilation and rubisco efficiency were higher in the biodynamic treatment (Fig. 2E). 

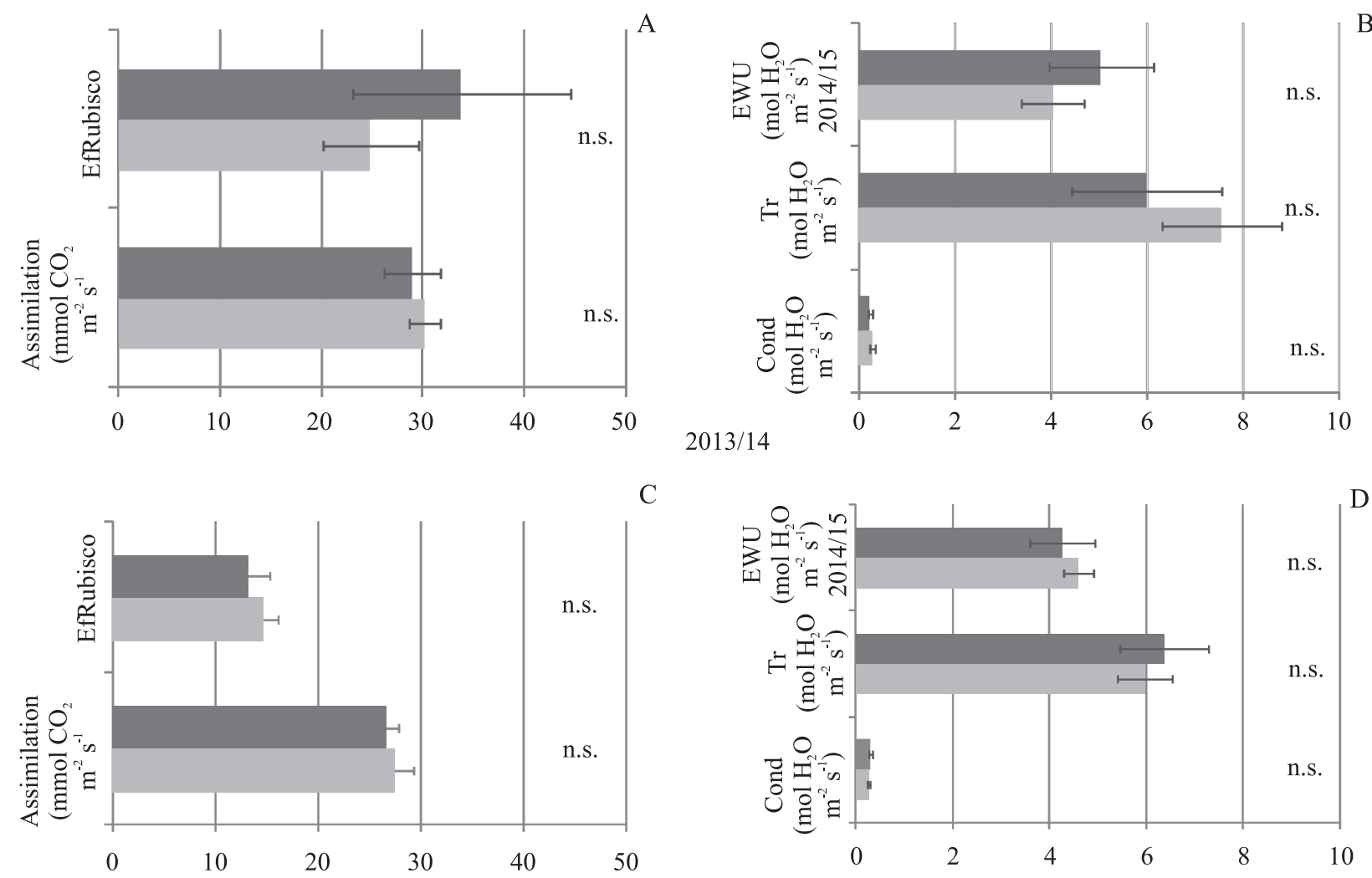

C
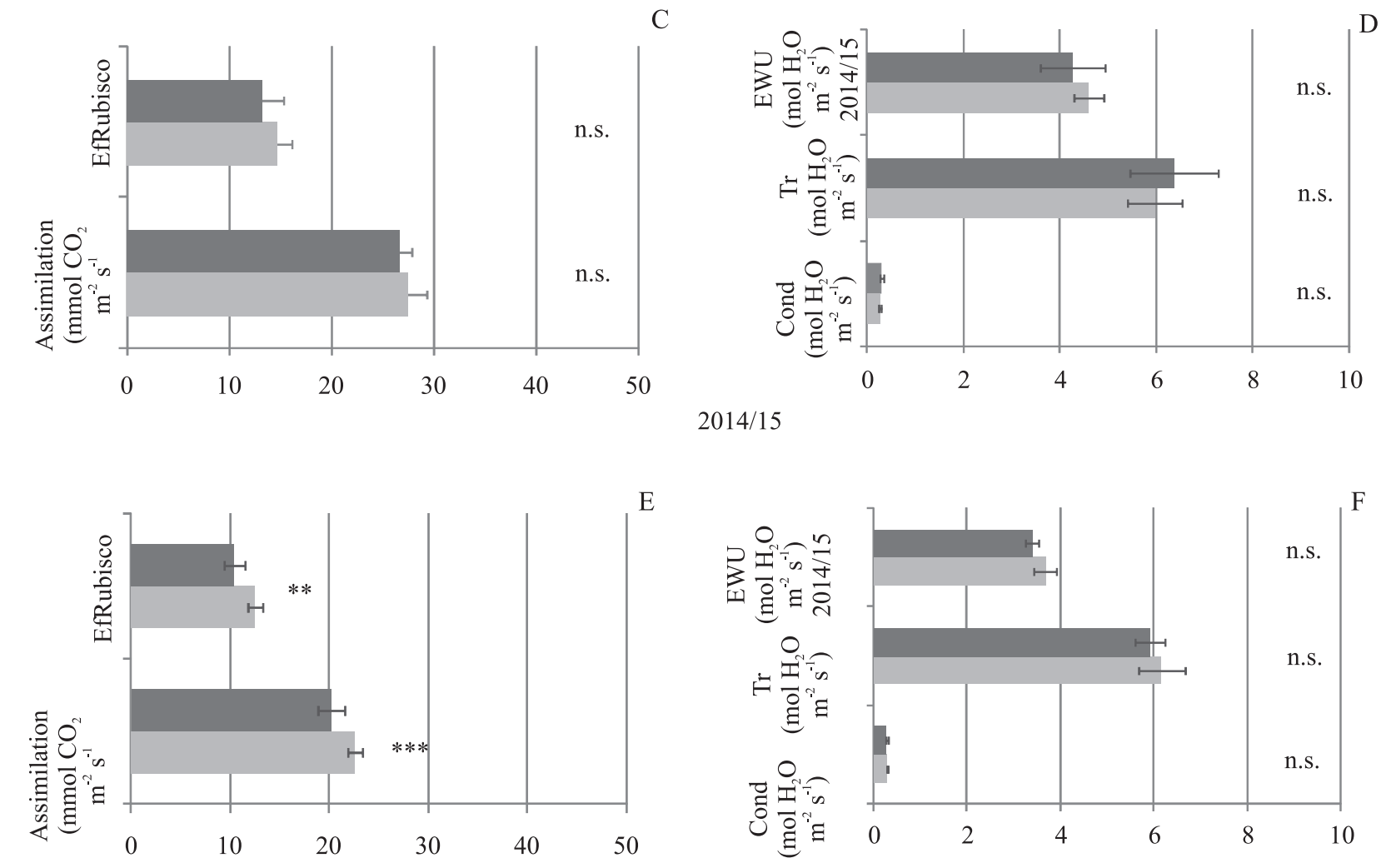

2014/15

E

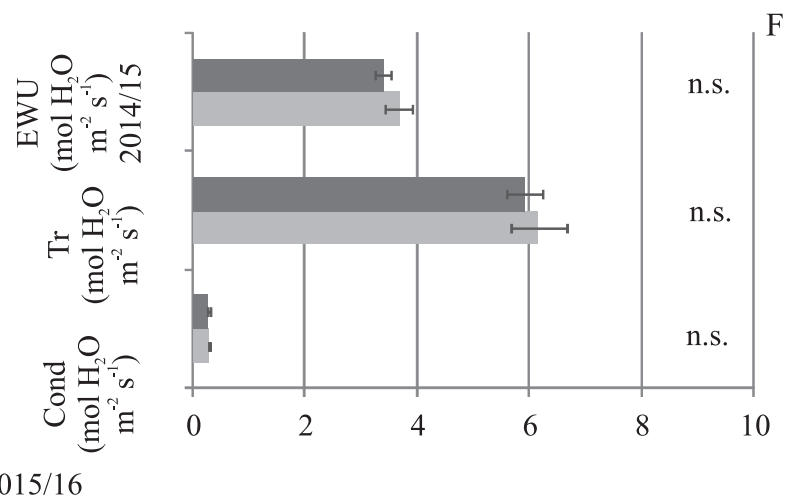

$\square$ Organic $\square$ Biodynamic

Figure 2 - Photosynthetic parameters. $\mathrm{CO}_{2}$ Assimilation and Rubisco Efficiency (Ef Rubisco) cycle 2013/14 (A), cycle 2014/15 (C) and cycle 2015/16 (E). Water use efficiency (WUE), Transpiration (Tr) and Stomatal conductance (Cond) cycle 2013/14 (B), cycle 2014/15 (D) and 2015/16 (F) of grape cv. BRS Carmem, Guarapuava-PR, 2016, for the treatments organic and biodynamic. Differ by the T test $-\operatorname{LSD} *(\mathrm{p} \leq 0.10), * *(\mathrm{p} \leq 0.05), * * *(\mathrm{p} \leq 0.01)$, n.s. no significance 
Another parameter that confirms these results is the chlorophyll fluorescence, and it has been used to evaluate the photochemical efficiency and the general physiological state of the plants (Mouget \& Tremblin, 2002; Baker \& Rosenqvist, 2004). In general, the value of the maximum quantum efficiency $(\mathrm{Fv} / \mathrm{Fm})$ for most species varies from 0.78 to 0.83 (Osmond, 1994; Maxwell \& Johson, 2000). Very close to the values found in the experiment, especially in the 2015/16 cycle (Fig. 3B). Biodynamic plants presented higher values of maximum fluorescence (Fm) and variable (Fv) in the two cycles 2014/15 and 2015/16 and quantum yield of PSII (Fv/Fm).
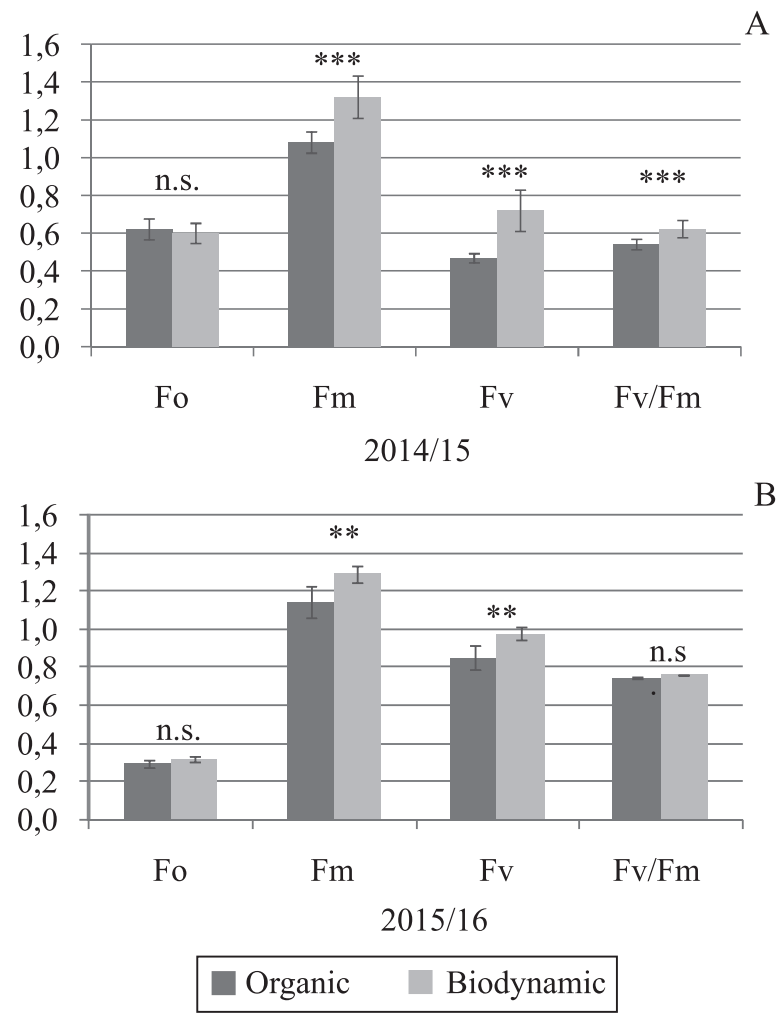

Figure 3 - Fluorescence of chlorophyll. Fluorescence minimum, (Fo), maximum fluorescence, (Fm), variable fluorescence (Fv) and maximum quantum yield of PSII (Fv/Fm), in cycles 2014/15 (A) and 2015/16 (B) of grape cv.BRS Carmem, Guarapuava-PR, 2016, for the treatments organic and biodynamic. Means followed by the same letter do not differ by the $\mathrm{T}$ test $-\mathrm{LSD} *(\mathrm{p} \leq 0.10)$, ** $(\mathrm{p} \leq 0.05), * * *(\mathrm{p} \leq 0.01)$, n.s. no significance.
Leaf enzymatic activities, severity of mildew and production

The activity of $\beta 1,3$ glucanases and chitinase enzymes were evaluated by three cycles, in which biodynamic treatment was superior in the second cycle for the enzyme $\beta 1,3$ glucanases and in the first and third cycles for the enzyme chitinase. For the enzyme $\beta 1,3$ glucanases, the biodynamic treatment was $76 \%$ higher than the organic treatment in the second cycle, and in the first and third there was no difference between the treatments but the standard remained the same. For the chitinase enzyme biodynamic treatment was $80 \%$ higher in the first cycle and $47 \%$ in the third cycle, but in the second there was no statistical difference (Table 2).

Table 2 - Activity of $\beta$ 1,3 glucanase and chitinase enzymes in grape cv. BRS Carmem cultivated in organic and biodynamic method during the vegetative period of 2013-2016

\begin{tabular}{lccc}
\hline \multicolumn{4}{c}{ Endochitinase } \\
\hline$\beta 1,3$ glucanase $\left(\mathrm{mg}^{-1} \mathrm{~h}^{-1} \mathrm{mg}^{-1}\right)^{I}$ \\
Treatment & $2013 / 14$ & $2014 / 15$ & $2015 / 16$ \\
Organic & 0.1452 & $0.3654 \mathrm{~b}$ & 0.4471 \\
Biodynamic & 0.2073 & $1.5245 \mathrm{a}$ & 0.9471 \\
Significance & $\mathrm{n} . \mathrm{s}$. & $* *$ & n.s. \\
Quitinase (U mg protein $\left.{ }^{-1}\right)^{2}$ & & \\
Organic & $0.0114 \mathrm{~b}$ & 0.0665 & $0.0113 \mathrm{~b}$ \\
Biodynamic & $0.0557 \mathrm{a}$ & 0.0803 & $0.0219 \mathrm{a}$ \\
Significance & $* *$ & n.s. & $* *$ \\
\hline
\end{tabular}

n.s.; ${ }^{* *}$, not significant; significant at $\mathrm{p} \leq 0.05$, respectively. ${ }^{l}$ Equivalent $1 \mathrm{mg}$ glucose per hour per $\mathrm{mg}$ protien. ${ }^{2}(\mathrm{U})$ Absorption unit $1 \mathrm{mg}$ protein per hour.

The area under the disease progress curve (AUDPC) was evaluated for three cycles. There was a statistical difference in the third evaluation cycle $(2015 / 16)$. The biodynamic treatment presented lower development of mildew, in which it was $27 \%$ less than the organic treatment. This result is in agreement with the greater enzymatic activity found in biodynamic treatment (Fig. 4).

For the productivity, berry diameter and average bunch weight (Fig. 5A and 5C), there were significant differences, and the biodynamic treatment presented, respectively, values $35 \%, 6.6 \%$ and $25 \%$ higher than organic treatment. For number and length of the bunches and for 
the solids content of the wort, there were no differences between the treatments (Fig. 5B and 5C).

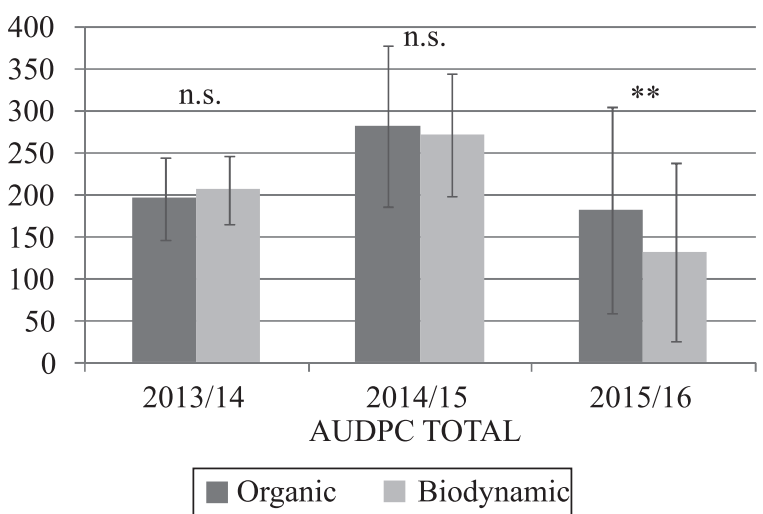

Figure 4 - Area under the disease progression curve (AUDPC), caused by Plasmopara viticola in the 2013/14, 2014/15 and 2015/16 cycles in grape BRS Carmem, Guarapuava-PR, 2016, for the treatments organic and biodynamic. Differ by the $\mathrm{T}$ test - LSD $*(\mathrm{p} \leq 0.10)$, $* *(\mathrm{p} \leq 0.05), * * *(\mathrm{p} \leq 0.01)$, n.s. no significance.

The efficiency of the biodynamic preparations was associated with effects on leaf enzymatic activity. The enzymes foliar $\beta$ 1,3 glucanases and chitinases have been used to prove mechanisms of defense of plants against pathogens, as they degrade the polysaccharides chitin and $\beta$ 1,3 glucan (Lebeda et al., 2001). In all cycles, biodynamic treatment showed an increase in leaf enzymatic activity, in the first and third cycles for chitinase and in the second for $\beta$ 1,3 glucanase (Table 2). The results of Botelho et al. (2016) in experiment with cv. Sangiovese show that biodynamic treatments show increased foliar enzyme activity for $\beta \mathrm{N}$ acetylhexosaminidase, 1,4 $\beta$ chitobiosidase and 1,3 $\beta$ glucanase. Magnin-Robert et al. (2013) show a relationship between the increase of these enzymes and the reduction of symptoms caused by Botrytis cinerea. These results are in agreement with those found in the third cycle of the experiment (Fig. 4), in which the plants treated with biodynamic preparations showed a lower incidence of Plasmopara viticola when compared to the field standard. Konig (2000) has shown that the prepared oak bark (505) induces resistance to diseases in zucchini plants.

According to Botelho et al. (2016), the use of biodynamic preparations makes the plants more prepared to biotic and abiotic stresses, thus stimulating the natural defense of plants. All these results reflect a better growth and phytosanitary status of plants treated with the biodynamic preparations. In the third cycle of 2015/16 the productivity, berry diameter and average bunch weight were higher in the biodynamic treatment, although the bunches length and soluble solids content did not present statistical difference (Fig. 5A, B and C).

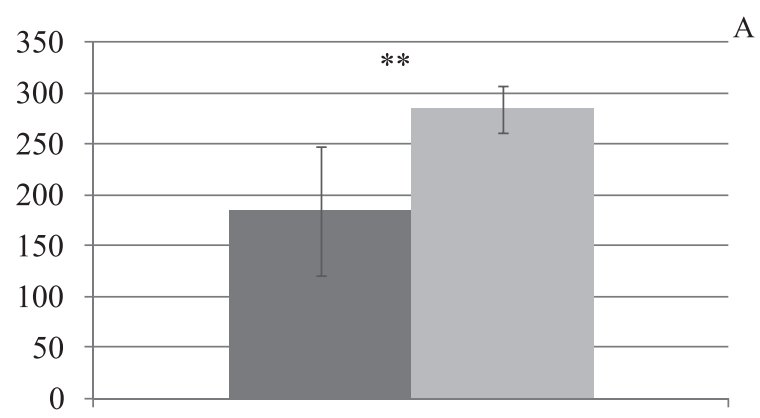

Productivity per hectare
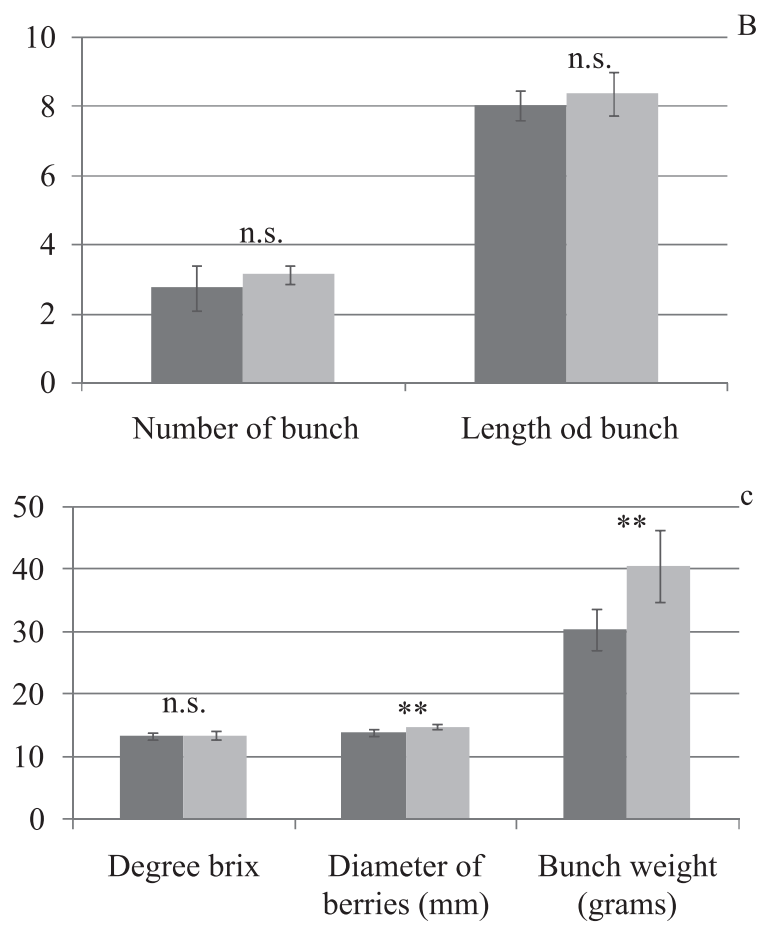

Organic Biodynamic

Figure 5 - Productivity per hectare (A), number of bunches and length of bunch (B), Degree brix, diameter of berries and average weight of bunches (C) of grape cv. BRS Carmem to field cycle 2015/16, Guarapuava-PR, 2016, for the treatments organic and biodynamic. Differ by the T test $\operatorname{LSD} *(\mathrm{p} \leq 0.10), * *(\mathrm{p} \leq 0.05), * * *(\mathrm{p} \leq 0.01)$, n.s. no significance. 


\section{CONCLUSIONS}

Biodynamic plants presented a larger length and diameter of the canes, larger diameter of the trunk and Spad index in at least one cycle evaluated. The physiological parameters showed a better efficiency of biodynamic plants in the third cycle.

The use of biodynamic preparations induces the activity of $\beta 1,3$ glucanase enzymes and chitinase in the leaves and may have contributed to the lower severity of mildew Plasmopara viticola. Productivity, although low for the first cycle, was higher for biodynamic treatment. Further studies in the future need to be developed to prove the efficacy of these preparations and make our way of growing more natural.

\section{ACKNOWLEDGMENTS}

Coordenação de Aperfeiçoamento de Pessoal de Nível Superior (CAPES) for the doctorate scholarship to Rafael Piva.

\section{REFERENCES}

AL-AGHABARY, K.; ZHU, Z.; SHI, Q.H. Influence of silicon supply on chlorophyll 49 content, chlorophyll fluorescence, and antioxidative enzyme activities in tomato plants under salt stress. Journal of Plant Nutrition, v.27, n.12, p. 2101-2115, 2004.

BAKER, N.R.; ROSENQVIST, E. Applications of chlorophyll fluorescence can improve crop production strategies: an examination of future possibilities. Journal of Experimental Botany, v.55, p.1607-1621, 2004.

BOTELHO, R.V.; ROBERTI, R.; TESSARIN, P.; MINA, J.M.G.; ROMBOLÀ, A.D. Physiological responses of grapevines to biodynamic manegement. Renewable Agriculture and Food Systems, v.31, p.402-413, 2016. doi:10.1017/S1742170515000320.

BRADFORD, M. M. A rapid and sensitive method for the quantitation of microgram quantities of protein utilizing the principle of protein-dye binding. Analytical Biochemistry, v.72, p.248-254, 1976.

BUFFARA, C. R. S.; ANGELOTTI, F.; VIEIRA, R. A.; BOGO, A.; TESSMANN, D. J.; DE BEM B. P. Elaboration and validation of a diagrammatic scale to assess downy mildew severity in Grapevine. Ciência Rural, Santa Maria, v.44, n.8, p.1384-1391, 2014. doi:10.1590/0103$8478 \mathrm{cr} 20131548$.
CARPENTER-BOGGS, L.; REGANOLD, J.P.; KENNEDY, A.C. Effects of biodynamic preparations on compost development. Biological Agriculture and Horticulture, v.17, p.313-328, 2000.

DEFFUNE, G.; SCOFIELD, A.M. Effects of humic acids and three bio-dynamic preparations on the growth of wheat seedlings. In: Cook, H.F., Lee, H.C. (eds.) Soil Management in Sustainable Agriculture. Proceedings of the Third International Conference on Sustainable Agriculture, Wye College, University of London, UK. pp. 364-371, 1995.

DEMETER. Demeter Product data base. 2016. Disponível em: < http:// database.demeter.net/prpub> (acessado em 01 agosto de 2016).

DEMETER. Demeter Product data base. 2016. Disponível em: < http:// database.demeter.net/prpub> (acessado em 01 agosto de 2016).

FERREIRA, D. F. Sisvar: a Guide for its Bootstrap procedures in multiple comparisons. Ciência agrotécnica [online], v.38, n.2 [citado 2015-10-17], p.109-112, 2014. Disponivel em: ISSN 1413-7054.<http://dx.doi. org/10.1590/S1413-70542014000200001>.

FLIESSBACH, A.; OBERHOLZER, H.R.; GUNST, L.; MÄDER, P. Soil organic matter and biological soil quality indicators after 21 years of organic and conventional farming. Agriculture, Ecosystems and Environment, v.118, p.273-284, 2007.

HALL, D.O., SCURLOCK, J.M., BOLHÀRNORDENKAMPF, H.R., LEEGOOD, R.C.; LONG, S.P. Photosynthesis and production in a changing environment. A field and laboratory manual. Londres: Chapman \& Hall, 1993, 464p.

IBD Instituto Biodinâmico. Produtos e Clientes Certificados. Disponível em: <http://ibd.com.br/pt/ ProdutosClientesAprovados.aspx $>$ (acessado em 08 dezembrode 2016).

JOVCHELEVICH, P.; VIDAL, A. Calendário Biodinâmico. Associação Brasileira de Agricultura Biodinâmica, Botucatu: Destak, 2016. 195p.

KLETT, M. Princípios dos preparados biodinâmicos de aspersão e de composto. Botucatu: Associação Brasileira de Agricultura Biodinâmica, 2012. 108p.

KÖNIG, U.J. Optimization of Biodynamic Preparations. Oak Bark Preparation. In: Proceedings 13th International IFOAM Scientific Conference, Basel, Switzerland, 2000.

LEBEDA, A.; LUHOVÁ, L.; SEDLÁROVÁ, M.; JANCOVÁ, D. The role of enzymes in plant-fungal 
pathogens interactions: review. Journal of Plant Diseases and Protection, v.108, p.89-111, 2001.

LEVER, M. A new reaction for colorimetric determination of carbohydrates. Analytical Biochemistry, v.47, p.273-279, 1972.

LORENZ, D.H.; EICHORN, K.W.; BLEHOLDER, H.; KLOSE, R.; MEIER, U.; WEBER, E. Phenological growth stages of grapevine (Vitis vinifera L.) - Codes and descriptions according to the extended $\mathrm{BBCH}$ scale. Australian Journal of Grape and Wine Research, Glen Osmond, v.1, p.100-103, 1995.

LUSSO, M.F.G., PASCHOLATI, S.F. Activity and isoenzymatic pattern of soluble peroxidases in maize tissues after mechanical injury or fungal inoculation. Summa Phytopathologica. v.25, p.244-249. 1999.

MAXWELL, K.; JOHSON, G.N. Chlorophyll fluorescence - a practical guide. Journal of Experimental Botany, v.51, p.659-668, 2000.

MA, J. F.; YAMAJI, N. Functions and transport of silicion in plants. Cellular and Molecular Life Sciences, v.65, p 3049-3057, 2008.

MAGNIN-ROBERT, M., QUANTINET, D., COUDERCHET, M., AZIZ, A.,AND TROTEL-AZIZ, P. Differential induction of grapevine resistance and defense reactions against Botrytis cinerea by bacterial mixtures in vineyards. BioControl, v.58, p.117-131, 2013.

MAPA, Instrução normativa 46/2011. Disponível em: $<$ http://www.agricultura. gov.br/arq_editor/file/ Desenvolvimento_Sustentavel/Organicos/Legislacao/ Nacional/Instrucao_Normativa_n_0_046_de_06-10 2011 regulada_pela_IN_17.pdf $>$ (Acessado em 10 janeiro de 2016).

MEDEIROS, N.; MACHADO, L.; LISBOA, R.S. Indentification of organic and byodinamic grape and wine producers in Southern Brazil. 37th World Congress of Vine and Wine and 12th General Assembly of the OIV. BIO Web of Conferences 3p, 2014. DOI: 10.1051/ bioconf/20140303005

MIKLÓS, A. A. W. A dissociação entre homem e natureza: reflexos no desenvolvimento humano. São Paulo: Antroposófica, 2001. 288p.

MOUGET, J.; TREMBLIN, G. Suitability of the fluorescence monitoring system (FM, Hansatech) for measurement of photosynthetic characteristics in algae. Aquatic Botany, v.74, p.219- 231, 2002.

OSMOND, C.B. What is photoinhibition? Some insights from comparisons of shade and sun plants. In:
BAKER, N.R.; BOWYER, J.R. (Ed.). Photoinhibition of photosynthesis, from molecular mechanisms to the field. Lancaster: Scientific Publishers, 1994. p.1-24.

PEFOLD, C.; JOHNSTON, L.; MARSCHNER, P.; BASTIAN, S.; COLINS, C. The relative sustainability of organic, biodynamic and conventional viticulture: Part 1: Soil health. Australian and New Zealand Grapegrower and Winemaker. v.616, p.40-44, 2015.

PIVA, R.; BOTELHO, R. V.; LIMA, P. C. G.; ROMBOLÀ, A. D. Development, physiology and occurrence of downy mildew in grapevine cv. BRS Margot treated with biodynamic preparations. Revista de Ciências Agrárias, v.42, n.2, p.472-482, 2019.

PORRO, D.; BERTAMINI, M.; DORIGATTI, C.; STEFANINI, M.; CESCHINI, A. 2001. Lo SPAD nella diagnosi dello stato nutrizionale della vite. Informatore Agrario, Verona, v.57, n.26, p.49-55, 2001.

RAUTA, J.; FAGUNDES, J. R.; SEHNEM, S. Gestão ambiental a partir da produção biodinâmica: uma alternativa à sustentabilidade em uma vinícola catarinense. Revista de Gestão Ambiental e Sustentabilidade, v.3, n.3, p.135-154, 2014.

REGANOLD, J. P.; PALMER, A. S. Significance of gravimetric versus volumetric measurements of soil quality under biodynamic, conventional, and continuous grass management. Journal of Soil and Water Conservation, v.50, n.3, p.298-305, 1995.

REEVE, J.R.; CARPENTER-BOOGS, L.; REGANOLD, J.P.; YORK, A.L.; MCGOURTY, G.; MCLOSKEY, L.P. Soil and wine grape quality in biodynamically and organically managed vineyards. American Journal of Viticulture and Enology, v.54, n.4, p.367-376, 2005.

SHANER, G.; FINNEY, R.E. The effect of nitrogen fertilization on the expression of slow-mildewing resistance in Knox wheat. Phytopathology, v.67, n.8, p.1051-1056, 1977.

SCHOLANDER, P.F.; HAMMEL, H.T.; BRADSTREET, E.D.; HEMMINGSEN, E.A. Sap pressure in vascular plants. Science, v.148, p.339-346, 1965.

SPACCINI, R., MAZZEI, P., SQUARTINI, A., GIANNATTASIO, M., AND PICCOLO, A. Molecular properties of a fermented manure preparation used as field spray in biodynamic agriculture. Environmental Science and Pollution Research, v.19 p.4214-4225, 2012.

STEINER, R. Fundamentos da agricultura biodinâmica: vida nova para a terra. 3.ed. São Paulo: Antroposófica, 1924. 239p. 
TAKAHASHI, E. Uptake mode and physiological functions of sílica. Science Rice Plant, v.2, p.58-71, 1995.

VOGELSANG, R.; BARZ, W. Purification, characterization and hormonal regulation of a $\beta$-1,3-glucanase and two chitinases from chickpea (Cicer arietinum L.). Planta, v.189 p.60-69, 1993.

ZALLER, J.G. AND KÖPKE, U. Effects of traditional and biodynamic farmyard manure amendment on yields, soil chemical, biochemical and biological properties in a long-term field experiment. Biology and Fertility of Soils, v.40, p.222-229, 2004.

WIRTH, S. J.; WOLF, G. A. Dye-labelled substrates for the assay and detection of chitinase and lysozyme activity.
Journal of Microbiological Methods, v.12, p.197-205, 1990.

WILLER, H.; LERNOUD, J. (Eds.). The World of Organic Agriculture. Statistics and Emerging Trends 2016. Research Institute of Organic Agriculture (FiBL), Frick, and IFOAM - Organics International. Bonn: IFOAM, 2016. 337p.

WREGE, M.S.; STEINMETZ, S.; REISSER JUNIOR, C.; ALMEIDA, I.R. Atlas climático da Região Sul do Brasil: Estados do Paraná, Santa Catarina e Rio Grande do Sul. 1. Pelotas: Embrapa Clima Temperado; Colombo: Embrapa Florestas, 336p. 2011.

Recebido para publicação em 23/01/2020, aprovado em 07/04/2020 e publicado 30/07/2020. 